\title{
Effects of a textile azo dye on mortality, regeneration, and reproductive performance of the planarian, Girardia tigrina
}

\author{
Alyson Rogério Ribeiro and Gisela de Aragão Umbuzeiro*
}

\begin{abstract}
Background: Many dyes can be considered emerging contaminants. The most widely used dyes belong to the class of azo compounds, some of which are known to have toxic and genotoxic properties. They are used in great quantities in textile activities and are of environmental concern because of their potential discharge in water. Planarians have been successfully used as test organisms in hazard evaluation of different chemicals, and we demonstrate the suitability of Girardia tigrina for laboratory testing. The aim of this work was to evaluate the suitability of the planarian species G. tigrina to assess the ability of the azo textile dye disperse red 1 to cause acute toxicity and adverse effects in the regeneration and reproduction of newborn and adult specimens.

Results: Disperse red 1 presented a median $L C_{50}$ of 75 and $152 \mathrm{mg} / \mathrm{L}$, respectively, for newborns and adults of G. tigrina, showing that newborns are twice as susceptible to the dye. Uncoordinated movements, irregular twists, colored skin, increased mucous production, and regenerative delays were observed after dye exposure at sub-lethal concentrations.

Conclusions: A no-observed-adverse-effect concentration (NOAEC) of $0.1 \mathrm{mg} / \mathrm{L}$ could be determined for disperse red 1 based on the fecundity test. Zinc seems to be a suitable positive control for monitoring the sensitivity in G. tigrina tests within only $24 \mathrm{~h}$ of exposure. This study demonstrates the applicability of $\mathrm{G}$. tigrina tests in the hazard evaluation of water contaminants, such as azo dyes.
\end{abstract}

Keywords: Regeneration; Planarians; Reproductive performance; Azo dye; Disperse red 1; Girardia tigrina

\section{Background}

Synthetic dyes can be considered emerging contaminants because they are potentially toxic and have been found in the aquatic environment and there are no regulations stating the maximum allowable concentrations in water to ensure the protection of aquatic biota and human health. The world production of key dyes is estimated to be more than 10 tons per year [1]. The most widely used dyes belong to the class of azo compounds derived from certain aromatic amines and are used in products such as textiles, foodstuffs, cosmetics, house products, paints, and inks. This is significant because some of these dyes are known to have potential toxic and genotoxic properties $[2,3]$. The use of azo dyes to the color of textiles is of considerable

\footnotetext{
* Correspondence: giselau@ft.unicamp.br

School of Technology, State University of Campinas - UNICAMP, Paschoal Marmo Street 1888, Limeira, SP 13484-332, Brazil
}

interest, as this can raise environmental concerns because of the high volume of water involved in the dyeing process. When a dye is used in this process, a portion does not undergo bonding to the fibers thus remaining in the water bath [4]. As a consequence, high volumes of wastewaters containing dyes and related auxiliaries are produced and may be released into the environment. For instance, for $10 \mathrm{~kg}$ of polyester fabric, $100 \mathrm{~g}$ of disperse red 1 will be dissolved in $200 \mathrm{~L}$ of water, of which are round $1 \%$ of the dye will remain in the water bath at the end of the process. Hence, around $200 \mathrm{~L}$ of wastewater containing $1 \mathrm{~g}$ of the dye will be generated. It is also known that conventional treatments involving aerobic lagoons or activated sludge are not efficient in the removal or biological degradation of these dyes [5] and therefore, the dyes are still present in the final effluent or in the sludge of the treatment plant [6,7]. Disperse dyes used to dye synthetic fibers are generally sparingly water-soluble 
compounds, but they can be found in the water column, because of their commercial formulation that includes surfactants needed for the dyeing process. Some disperse dyes have been found in the aquatic environment [8], and their presence was related to the observed mutagenic activity of the water and sediments $[6,7,9]$.

Recently, Ferraz et al. [10] showed that the textile dye disperse red 1 ((N-ethyl- $N$-(2-hydroxyethyl)-4-(4-nitrophenylazo) aniline) is highly toxic to aquatic invertebrates, in addition to being mutagenic. Vacchi et al. [11] studied a commercial disperse red 1 dye product and found that the ecotoxicity of the commercial preparation was similar to the dye itself. The median effective concentration $\left(\mathrm{EC}_{50}\right)$ for Daphnia was $0.1 \mathrm{mg} / \mathrm{L}$; therefore, this dye can be classified as highly toxic to aquatic organisms according to the Globally Harmonized System of Classification and Labelling of Chemicals (GHS) [12]. More recently, studies have been performed to estimate the concentrations of dyes in surface waters [13], Zocollo et al.'s submitted article. The authors determined the concentrations of disperse azo dyes in river and effluent samples collected in Brazil and showed that they were present in the levels of nanograms to micrograms per liter. However, more studies are required to estimate the concentration levels in the aquatic environment, especially in countries where dyeing activities are more intense, like in India, China, and Brazil.

Planarians have been used as test organisms in the hazard evaluation of different chemicals using different endpoints such as mortality, regeneration, micronucleus (MN) frequency, and enzymatic activity [14-21]. Planarians generally reproduce by transverse fission, but some species, like Girardia tigrina [22], also have hermaphroditic sexual organs and can generate cocoons of fertilized eggs [23]. Therefore, reproduction impairment can also be used as an endpoint in ecotoxicity tests with planarians $[20,22]$.

Because of its ability to regenerate [24,25], planarians have been used to verify if chemicals can interfere with this process $[17,18,26-30]$. A small body fragment can generate an intact planarian due the presence of totipotent stem cells called neoblasts, which migrate from the parenchymal tissue to the injured site and differentiate by mitosis to other planarian cell types [31,32].

There have been a number of publications that examined the response of planarians to chemical exposures using molecular and enzymatic approaches [21,33-35]. We focused our study towards three different low-cost and environmentally relevant endpoints: mortality, regeneration, and reproduction. The aim of this work was to evaluate the suitability of the planarian species $G$. tigrina as a test organism to assess the acute toxicity of the azo textile dye, disperse red 1, to newborns and adults and to verify its ability to cause adverse effects on regeneration and cocoon production in the exposed animals.
Disperse red 1 was selected because it has been found in river waters that receive textile effluents in the region of Americana, São Paulo, Brazil (Zocolo et al.'s submitted article).

\section{Results and discussion}

G. tigrina showed an acceptable sensitivity to $\mathrm{ZnSO}_{4}$, with a 24-h median lethal concentration of $\mathrm{LC}_{50}$ of $1.6 \pm$ $0.2 \mathrm{mg} / \mathrm{L}$ expressed in $\mathrm{Zn}^{2+}$ and a variation coefficient of $12 \%$ in seven replicate acute newborn toxicity tests (Table 1). Chromium salts have previously been used to monitor sensitivity of laboratorial culture $[15,36,37]$. We also used chromium for this purpose but zinc provided better repeatability and faster responses $(24 \mathrm{~h})$ (Table 1$)$. Although the mean $\mathrm{LC}_{50}$ values after 48 and $96 \mathrm{~h}$ for chromium are similar to those reported by Preza and Smith [15], the coefficient of variation (66\%) in our study was higher than obtained by those authors (22\%). This higher variation could be explained by the higher instability of chromium in solutions compared to zinc or by response differences between the planarian populations.

The $\mathrm{LC}_{50}$ values for disperse red 1 dye obtained with newborns and adults are presented in Table 2, and as expected, toxicity increased with exposure time. Three independent tests were performed, and the coefficients of variation of the means were below $17 \%$, which was considered acceptable for ecotoxicological assays according to the recommendation of Environment Canada [38]. No mortality was observed when adults were exposed during the first $24 \mathrm{~h}$ but several animals showed uncoordinated movements and increased mucus production at all tested concentrations. Mean $96-\mathrm{h} \mathrm{LC}_{50}$ values of $75 \pm$ $7.2 \mathrm{mg} / \mathrm{L}(n=3)$ and $152 \pm 5.8(n=3) \mathrm{mg} / \mathrm{L}$ were obtained

\section{Table 1 Mean lethal concentrations $(50 \%)\left(L_{50}\right)$ of chromium and zinc in newborn G. tigrina acute tests for sensitivity assessment}

\begin{tabular}{|c|c|c|c|c|c|c|c|c|}
\hline \multirow{3}{*}{ Test } & \multicolumn{8}{|c|}{$\mathrm{LC}_{50}(\mathrm{mg} / \mathrm{L})$} \\
\hline & \multicolumn{4}{|c|}{$\mathrm{Cr}^{6+}$} & \multicolumn{4}{|l|}{$\mathrm{Zn}^{2+}$} \\
\hline & $24 \mathrm{~h}$ & $48 \mathrm{~h}$ & $72 \mathrm{~h}$ & $96 \mathrm{~h}$ & $24 \mathrm{~h}$ & $48 \mathrm{~h}$ & $72 \mathrm{~h}$ & $96 \mathrm{~h}$ \\
\hline I & 13 & 11 & 8 & 7 & 2 & 2 & 2 & 2 \\
\hline$\|$ & 11 & 11 & 11 & 7 & 1.6 & 1.6 & 1.6 & 1.6 \\
\hline III & * & 27 & 20 & 11 & 1.6 & 1.6 & 1.6 & 1.6 \\
\hline IV & * & 29 & 18 & 15 & 1.6 & 1.6 & 1.6 & 1.6 \\
\hline V & 18 & 8 & 5 & 3 & 1.3 & 1.3 & 1.3 & 1.3 \\
\hline VI & 15 & 10 & 5 & 4 & 1.6 & 1.6 & 1.6 & 1.6 \\
\hline VII & 14 & 5 & 2 & 5 & 1.7 & 1.7 & 1.7 & 1.7 \\
\hline Mean & 14.2 & 14.4 & 9.8 & 7 & 1.6 & 1.6 & 1.6 & 1.6 \\
\hline $\mathrm{SD}^{\mathrm{a}}$ & 2.5 & 9.5 & 6.8 & 4.6 & 0.2 & 0.2 & 0.2 & 0.2 \\
\hline$C V(\%)^{b}$ & 18 & 66 & 69 & 66 & 12 & 12 & 12 & 12 \\
\hline
\end{tabular}

Asterisk indicates $\mathrm{LC}_{50}$, not calculable for the statistical method employed. ${ }^{\mathrm{a}} \mathrm{SD}$ standard deviation of the mean. ${ }^{\mathrm{b}}$ Coefficient of variation. The tests indicated as I, II, III, IV, V, VI, and VII correspond to independent experiments. 
Table 2 Mean lethal concentrations $(50 \%)\left(\mathrm{LC}_{50}\right)$ of commercial disperse red 1 in newborn and adult G. tigrina tests

\begin{tabular}{|c|c|c|c|c|c|c|c|c|}
\hline \multirow{3}{*}{ Test } & \multicolumn{8}{|c|}{$\mathrm{LC}_{50}(\mathrm{mg} / \mathrm{L})$} \\
\hline & \multicolumn{4}{|c|}{ Newborn } & \multicolumn{4}{|c|}{ Adult } \\
\hline & $24 \mathrm{~h}$ & $48 \mathrm{~h}$ & $72 \mathrm{~h}$ & $96 \mathrm{~h}$ & $24 \mathrm{~h}$ & $48 \mathrm{~h}$ & $72 \mathrm{~h}$ & $96 \mathrm{~h}$ \\
\hline I & 127 & 127 & 74 & 67 & * & 201 & 179 & 159 \\
\hline$\|$ & 120 & 91 & 79 & 79 & * & 207 & 156 & 148 \\
\hline III & 131 & 111 & 87 & 80 & * & 198 & 162 & 150 \\
\hline Mean & 126 & 110 & 80 & 75 & & 202 & 167 & 152 \\
\hline$S D^{a}$ & 5.6 & 18 & 6.5 & 7.2 & & 4.6 & 12 & 5.8 \\
\hline$C V(\%)^{b}$ & 4.4 & 16.4 & 8.1 & 9.6 & & 2.2 & 7.2 & 3.8 \\
\hline
\end{tabular}

Asterisk indicates no mortality was observed. ${ }^{a} \mathrm{SD}$ standard deviation of the mean. ${ }^{b}$ Coefficient of variation. The tests indicate as I, II, and III correspond to independent assays.

for newborns and adults, respectively (Table 2). These results confirmed the findings of Preza and Smith [15] which showed that newborns were more sensitive than adults. Knakievicz and Ferreira [20] attributed this age response to different body surface/volume ratios of newborn organisms.

Ecotoxicological data of azo textile dyes are scarce in the literature. Ferraz et al. [10] tested disperse red 1 ( $95 \%$ purity) and obtained an $\mathrm{EC}_{50}$ of $0.13 \mathrm{mg} / \mathrm{L}$ in a Daphnia similis acute toxicity test. Recently, the same commercial product that was analyzed in this study was used in acute toxicity tests with D. similis and Hydra attenuata [11]. The authors showed that the surfactant and other impurities present in the commercial dye did not influence the observed toxicity, at least for Daphnia. The observed effects were related to the main dye, which represents $60 \%$ of the commercial product. In that study, it was not possible to verify if the acute toxicity observed for Hydra was related also to the main dye, but Hydra was 15 times less sensitive than Daphnia to the commercial dye [11].

Aggregation and precipitation of the dye were observed at concentrations higher than $50 \mathrm{mg} / \mathrm{L}$ after the first $24 \mathrm{~h}$ of exposure. This is expected because the commercial dye contains surfactants. Therefore, when the concentration of the disperse dye increases, they can form aggregates and settle on the bottom. This behavior is also expected to occur in the aquatic systems [39]. Because planarians slide on the surface of the testing containers [40], the animals were exposed to the precipitated/ agglomerated dye in addition to the dye remaining in the solution. This natural surface-contact behavior of the planarians is an important consideration when assessing the toxicity of compounds that are sparingly soluble in water.

After $24 \mathrm{~h}$ of exposure in the acute toxicity tests, newborns (Figure 1) and adults (not shown) exposed to concentrations higher than $10 \mathrm{mg} / \mathrm{L}$ showed red-colored

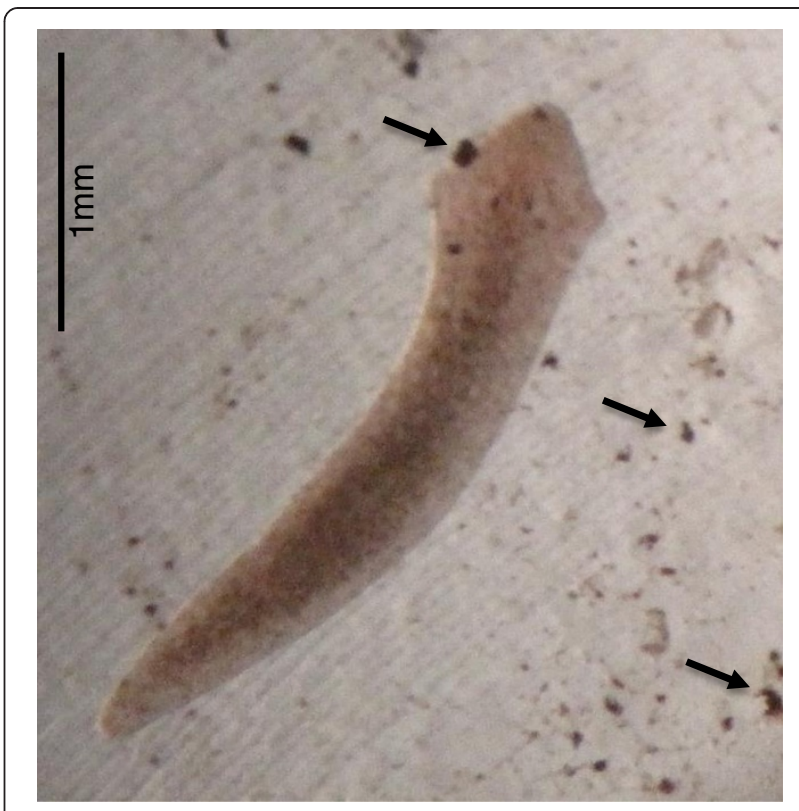

Figure 1 Picture of a newborn of G. tigrina after 96-h exposure to $10 \mathrm{mg} / \mathrm{L}$ of commercial disperse red 1 dye. Red-colored skin can be observed. Arrows indicate the precipitation and agglomeration of the dye. The image is 50 times increased.

skin, especially at the encephalic region. This could be explained by dermal or cilia dye adsorption during locomotion and/or skin respiration. The exposed organisms showed uncoordinated movements, irregular twists and increased mucous production after the first 24-h exposure. The mucous resulted in dye precipitation and aggregation around the animal bodies, forming what appeared to be a body capsule, which was abandoned when the planarians started to move. Planarian behavioral effects, such as increased mucus production, irregular twisting, and body contractions, have previously been associated with animal responses to toxicants [26,41,42].

In the regeneration assay, the first changes were observed after $24 \mathrm{~h}$ at the highest concentration tested, 200 $\mathrm{mg} / \mathrm{L}$. After $120 \mathrm{~h}, 95 \%$ of control planarians fully regenerated (see Figure 2e). The no-observed-adverse-effect concentration (NOAEC) for the dye was $10 \mathrm{mg} / \mathrm{L}$ and the lowest-observed-adverse-effect concentration (LOAEC) was $50 \mathrm{mg} / \mathrm{L}$ (Table 2). The regenerated planarians showed also red-colored skin, behavioral changes, and increased mucous production at concentrations higher than $10 \mathrm{mg} / \mathrm{L}$. Regenerative delay started to occur at $50 \mathrm{mg} / \mathrm{L}$, while at the highest concentration $(200 \mathrm{mg} / \mathrm{L})$, eight of the 20 organisms died within $96 \mathrm{~h}$ of exposure, and the ones that survived presented severe regenerative delay after $120 \mathrm{~h}$ of exposure (Table 3) with parenchymal loss due to lack of wound cicatrization (see Figure 2c,d). When cicatrization occurred, some delays in posterior regenerative stages were noticed. In seven animals the auricle 

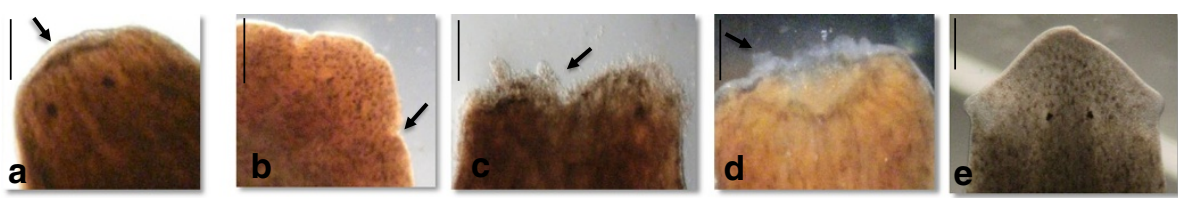

Figure 2 Morphological effects of different concentrations of commercial disperse red 1 dye in G. tigrina. (a) Individual without full body cicatrization, showing eyespots and no auricles (phase z) - after 120-h exposure at $200 \mathrm{mg} / \mathrm{L}$. (b) Late development of the auricle (phase d) after $120 \mathrm{~h}$ at $50 \mathrm{mg} / \mathrm{L}$. (c, d) Individuals with delayed and abnormal cicatrization (phase t) - after $120 \mathrm{~h}$ at $200 \mathrm{mg} / \mathrm{L}$. (e) A fully developed planarian with no effect (negative control). Arrows are guides to the eye and the bar on the left of each figure represent $1 \mathrm{~mm}$.

development was inhibited or delayed (see Figure 2a and $2 \mathrm{~b}$ ). For successful regeneration of the lost body parts, planarians need an intact nervous system to control the migration of the normal neoblasts $[43,44]$ that may have been affected by the dye. Also, the mutagenic properties of the dye $[10,11]$ could affect the normal mitotic process required for the cell replication, which is needed for regeneration. The planarian regeneration assays are useful for analyzing the effects of chemicals on cell differentiation and molecular organization [45]. Thus the migration and proliferation of neoblasts as well as other steps required to G. tigrina regeneration may have been affected by the azo dye.

Freshwater planarian reproduction is a complex process and some details are still unknown [22]. These animals have a many-sided reproductive organ with ovaries and hormones. Animals can be fertilized after mating $[23,46]$. Eggs, formed after fertilization, as well as vitelline cells, are enveloped by an oval wall called cocoons [47]. Hatching occurs after different incubation periods depending on the species and temperature $[40,48]$. The time between crosses and cocoon lay is still unknown. In our experiments, the fecundity index recorded for the animals exposed to $1 \mathrm{mg} / \mathrm{L}$ of disperse red 1 (stage 2, exposure) was statistically significantly lower than the control (Figure 3). Also, after the first week of exposure, animals from the treated group G4 $(1 \mathrm{mg} / \mathrm{L})$ presented colored skin and alterations in behavior during feeding, such as continuous exposure of the pharynx and limited mobility. The pharynx is only exposed during a planarian's feeding process, and after feeding this organ returns to planarian's gastric cavity [40]. However, we observed that planarians, when exposed to the dye, showed retractile pharynx movements even when they were far from the food. Planarian reproductive success is related to food availability, demographic density, and temperature $[22,48,49]$. During the entire exposure time, the animals from G4 group were not able to eat and the cocoons produced during that time may have been generated using their remaining energy $[36,50]$

During stages 1 (before exposure) and 3 (recovery following exposure) no statistical differences were observed in the fecundity indexes among the groups, although fecundity capacity did not seem to be fully recovered when animals were exposed to $1 \mathrm{mg} / \mathrm{L}$ during stage 3 (Figure 3). The addition of the recovery stage was also useful to analyze if the planarians were able to remove the impregnated or absorbed dye from their bodies and if the effect on the pharynx's retractability was permanent. After 2 weeks of recovering in maintenance water more than $80 \%$ of the exposed animals showed normal skin color as well as normal pharynx function and feeding behavior. Therefore, disperse red 1 interferes with G. tigrina's mobility and capacity for food identification at $1 \mathrm{mg} / \mathrm{L}$ exposure concentration. In sum, disperse red 1 dye adversely affects survival, fecundity, regeneration, and feeding behavior in

Table 3 Regenerative results for G. tigrina exposed to different concentrations of the commercial disperse red 1

\begin{tabular}{|c|c|c|c|c|c|c|}
\hline \multirow{2}{*}{$\begin{array}{l}\text { Exposure } \\
\text { time (h) }\end{array}$} & \multicolumn{6}{|c|}{ Planarians/regeneration steps (mg/L) } \\
\hline & Control & 10 & 50 & 100 & 150 & 200 \\
\hline 12 & $20^{a}(a)^{b}$ & $20(a)$ & $20(a)$ & $20(a)$ & $20(a)$ & $20(a)$ \\
\hline 24 & $20(b)$ & $20(b)$ & $20(b)$ & $20(b)$ & $20(b)$ & $3(\mathrm{t}) 17(\mathrm{~b})$ \\
\hline 48 & $20(c)$ & $20(c)$ & $20(c)$ & $20(c)$ & $20(c)$ & $3(t) 17(c)$ \\
\hline 72 & $20(\mathrm{de})$ & $20(\mathrm{de})$ & $20(\mathrm{de})$ & $2(c) 18(\mathrm{de})$ & $2(c) 18(\mathrm{de})$ & $3(\mathrm{t}) 17(\mathrm{de})$ \\
\hline 96 & $20(f)$ & $20(f)$ & $3(d) 17(f)$ & $5(d) 15(f)$ & $2(d) 18(f)$ & $3(\mathrm{t}) 9(\mathrm{~d}) 8(\mathrm{f})$ \\
\hline 120 & $1(f) 19(g)$ & $20(g)$ & $2(f) 18(g)$ & $5(f) 15(g)$ & $5(f) 15(g)$ & 8 dead 3(t) 3(z) 4(d) 2(g) \\
\hline $\mathrm{Pd}_{120 \mathrm{~h}}^{c}$ & & -1 & 1 & 4 & 4 & 9 \\
\hline
\end{tabular}

${ }^{a}$ Number of animals. ${ }^{b}$ Regeneration steps: (a) decapitated bodies, (b) beginning of blastema formation, (c) regular blastema, (d) beginning of auricle formation, (e) beginning of eyespots formation, (f) auricle and eyespots clearly defined, (g) full head formation, (t) body section without cicatrization, (z) without body cicatrization, with eyespots, and without auricle. ${ }^{C} \mathrm{Pd}$ is the number of planarians with delayed regeneration subtracted from the number of delayed planarians in the control, $\mathrm{Pd}$ greater or equal to 1 is considered as adverse, for more information see 'Methods' section. 


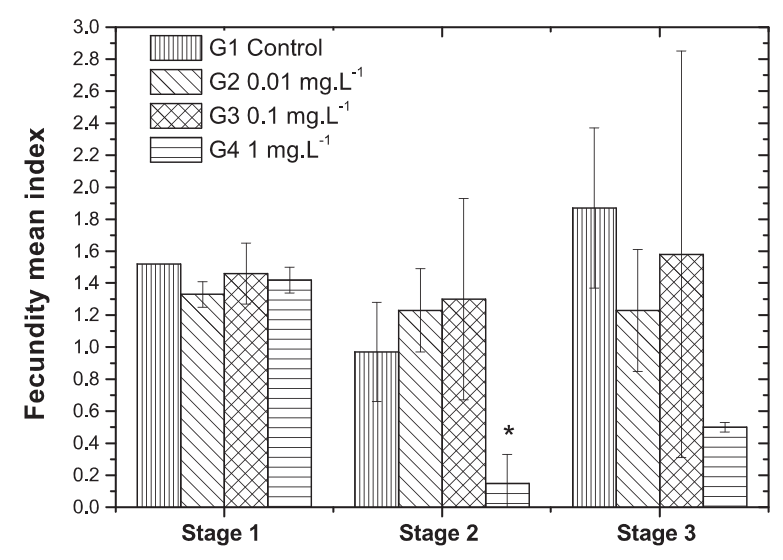

Figure 3 Mean fecundity index of G. tigrina planarian exposed to commercial textile dye disperse red 1 (control and exposed groups). At stage 1, exposure system adaptation, organisms were monitored for 2 weeks in maintenance medium. At stage 2, organisms were exposed for 5 weeks. At stage 3, recovery, exposed organisms were monitored for 2 weeks more in maintenance water. Bars represent the standard deviation of the mean. *Significant at $p \leq 0.05$.

planarians. Based on the most critical endpoint (fecundity index) it is possible to suggest a no-observed-adverseeffect-concentration (NOAEC) of $0.1 \mathrm{mg} / \mathrm{L}$ for disperse red 1. As observed in other studies $[15,17,21,22,49]$, the viability of $G$. tigrina culture under low-cost laboratorial conditions was confirmed. Our results also show the repeatability of the applied protocol at least for zinc and disperse red 1.

Planarians can be considered an interesting model for ecotoxicological assessment of environmental contaminants because it allows the assessment of different sublethal effects, such as increase in mucus production and changes in behavior besides the evaluation of adverse effects on the regeneration process and reproduction as showed in this work.

\section{Conclusions}

Disperse red 1 presented a median $\mathrm{LC}_{50}$ of 75 and 152 $\mathrm{mg} / \mathrm{L}$, respectively, for newborns and adults of G. tigrina, showing that newborns are more susceptible to the dye than adults. Uncoordinated movements, irregular twists, colored skin, and increased mucous production were observed after dye exposure at sub-lethal concentrations. A no-observed-adverse-effect concentration (NOAEC) of 0.1 $\mathrm{mg} / \mathrm{L}$ of disperse red 1 could be determined based on the fecundity test. Zinc seems to be a suitable reference substance for monitoring the sensitivity in G. tigrina tests within only 24 h of exposure. This study successfully demonstrates the applicability of G. tigrina tests in the hazard evaluation of azo dyes, a relevant example of an emerging contaminant. The results obtained in this work may also be used for the determination of safe environmental concentrations of disperse red 1 for the aquatic system.

\section{Methods}

Chemical

The powdered commercial textile dye product disperse red 1 dye ( $N$-Ethyl- $N$-(2-hydroxyethyl)-4-(4-nitrophenylazo) aniline; CAS No 2872-52-8), was purchased from PCIL(C) Dyes, São Paulo, Brazil. The product was chemically characterized by Vacchi et al. [11] and contains $60 \%$ of the main dye disperse red 1, 20\% of other azo dye products, and $20 \%$ of a surfactant. Zinc sulfate $\left(\mathrm{ZnSO}_{4} \cdot 7 \mathrm{H}_{2} \mathrm{O}\right.$; CAS No 7440-20-0; CAQ Casa de Química ${ }^{\circ}$, Diadema, São Paulo, Brazil) and potassium dichromate $\left(\mathrm{K}_{2} \mathrm{Cr}_{2} \mathrm{O}_{7}\right.$; CAS No 7778-50-9; Cromoline Química Fina@, Diadema, São Paulo, Brazil) in analytical grade were used as reference substances to monitor the sensitivity of the planarian culture. Dye and metal testing solutions were prepared in planarian maintenance water (see description below) in concentrations determined by preliminary tests.

\section{Animals}

Specimens of G. tigrina collected in a pristine pond in Rio Claro, São Paulo, Brazil [17], have been cultivated in the Ecotoxicology and Environmental Microbiology Laboratory (LEAL) in the University of Campinas, Limeira, Brazil, since 2005. Descendant animals were cultured by sexual reproduction at room temperature $\left(22\right.$ to $\left.25^{\circ} \mathrm{C}\right)$ under a light/dark photoperiod of 16:8 h, and fed once a week with bovine liver. The water for culturing the planarians and conducting experiments was designated as maintenance water and was prepared with dechlorinated tap water and $45 \mathrm{mg} \mathrm{CaCO}_{3} / \mathrm{L}, \mathrm{pH} 7.6 \pm 0.3$, and with gentle aeration [37] using an aquarium pump. Water was completely renewed each week after feeding.

\section{Toxicity tests}

Three environmentally relevant endpoints were investigated in this study through different toxicity tests: acute toxicity (mortality), regeneration assay and reproductive performance. Acute toxicity tests were carried out with adult and newborn planarians. Animals of more than 3 months of age and visible cocoon production capacity were considered adults, and animals with a maximum age of 10 days were considered newborns [15]. Each independent newborn toxicity test was carried out in duplicate using seven animals placed in $50 \mathrm{~mL}$ of test solution for $96 \mathrm{~h}$ [15]. In the adult toxicity tests healthy animals were randomly selected and five planarians were exposed to $100 \mathrm{~mL}$ of test solution. Each independent experiment was performed in triplicate [37]. In both the newborn and adult tests, the test solution was not renewed and the animals were not fed. Negative controls with maintenance water and positive controls with $\mathrm{ZnSO}_{4}$ 
and $\mathrm{K}_{2} \mathrm{Cr}_{2} \mathrm{O}_{7}$ were also performed. The nominal concentration used in the positive controls using chrome were $0.9,1.8,3.5,7,10,18$ and $35 \mathrm{mg} / \mathrm{L}$ expressed $\mathrm{as}^{6+}$ and using zinc were $0.1,0.2,0.5,1.1,2.2,4.5$, and $6.8 \mathrm{mg} / \mathrm{L}$, expressed as $\mathrm{Zn}^{2+}$. Mortality, body degeneration, change in behavior and morphological alterations were monitored every 24 hours under a stereo-microscope (Stemi 2000-C, Zeiss $\odot$, Oberkochen, Germany). The nominal dye concentrations tested were 10, 50, 100, 150, and $200 \mathrm{mg} / \mathrm{L}$ for newborns and 50, 100, 150, 200, and $250 \mathrm{mg} / \mathrm{L}$ for adults.

For the regeneration assay, the heads of adult planarians were removed in the region behind the auricles using blades, and the decapitated animals were used immediately [14]. The animals were fed 1 day before the test started to ensure that they would have sufficient nutrients to regenerate. This is important because G. tigrina has the ability to store vital nutrients [36] and the digestion and assimilation of food, in particular liver, takes about $197 \mathrm{~h}$ [50]. The concentrations of disperse red 1 used (10, 50, 100,150 and $200 \mathrm{mg} / \mathrm{L}$ ) were selected based on the toxicity test results. In each independent experiment, each concentration was tested using four replicates; five decapitated animals per replicate were put in $20 \mathrm{~mL}$ of solution. Each head regeneration step [17,31] (designated, a decapitated bodies; $\mathrm{b}$ beginning of blastema formation; c regular blastema; $d$ beginning of auricle formation; e beginning of eyespot formation; $\mathrm{f}$ auricle and eyespots clearly defined; $\mathrm{g}$ full head formation; and $\mathrm{t}$ body section without cicatrization, $\mathrm{z}$ without body cicatrization, with eyespots, and without auricle) were observed under the stereoscope daily, followed by renewal of the dye test solution [20]. Regeneration of decapitated planarians in maintenance water was used as a negative control. Animals were not fed, and they were kept in cultivation conditions for $120 \mathrm{~h}$ for full regeneration of the encephalic region [17].

The reproductive performance of adult specimens was evaluated based on a method described elsewhere [20]. The single experiment included a preexposure stage for adaptation purposes. We also followed the recovery capacity in a postexposure period, without the presence of the toxicant. Twenty-five healthy adult animals were randomly placed into plastic vessels containing $1 \mathrm{~L}$ of each test solution, without replicates. The test was carried out in three stages: at stage 1 (adaptation), all organisms were exposed only to maintenance medium and were monitored for 2 weeks. At stage 2 (toxicant exposure), three groups of organisms were exposed to sub-lethal concentrations $(0.01,0.1$, or $1 \mathrm{mg} / \mathrm{L})$ of the commercial product. We also included a negative control, without the dye. Concentrations were selected based on the acute toxicity test results. This stage lasted five weeks. At stage 3 (recovery), chemical exposure was interrupted at the end of the 5 weeks; animals were transferred into maintenance water and monitored for an additional 2 weeks.
Observations on cocoon production, animal behavior, and mortality were made during all stages. Identical cultivation maintenance procedures were used for all groups, with weekly feeding followed by total test solution renewal, and the counting and segregation of cocoons.

During the toxicity, reproductive, and regeneration experiments, any changes in animal behavior, skin color, and mucous production were registered on a daily basis. The retractability of the pharynx during feeding was also monitored.

\section{Statistical analysis and expression of the results}

For acute toxicity tests, the trimmed Spearman-Karber method [51] was used to calculate the $\mathrm{LC}_{50}$, with $95 \%$ confidence interval, for every $24 \mathrm{~h}$ of exposure, until 96 $\mathrm{h}$. In the regeneration tests, a 120 -h delayed regeneration value (Pd120h) was calculated for each concentration. To obtain this value, the number of delayed regeneration planarians in the control was subtracted from the treated number. The NOAEC was the higher concentration that presented a $\operatorname{Pd} 120 \mathrm{~h}<1$, and the LOAEC was the lowest concentration that presented a Pd120h $\geq 1$.

In the reproductive performance assay, the mean fecundity index for each group in each stage was calculated using a method adapted from Knakievicz et al. [22]. Mean fecundity indexes were calculated by the total number of cocoons divided by the number of live planarians in every analyzed week, divided by the total experimental time, in weeks, at the end of each step. To compare the different treatments, analysis of variance (ANOVA) followed by the Tukey test was performed using the Origin ${ }^{\oplus}$ Pro8 program. The significance level was $p \leq 0.05$.

\section{Abbreviations}

$\mathrm{LC}_{50}$ : median lethal concentration; $\mathrm{EC}_{50}$ : median effective concentration; GHS: Global Harmonization System; NOAEC: no-observed-adverse-effect concentration; LOAEC: lowest-observed-adverse-effect concentration; LEAL: Ecotoxicology and Environmental Microbiology Laboratory; CAS: Chemical Abstracts Service; Pd: delayed regeneration value; ANOVA: analysis of variance.

\section{Competing interests}

The authors declare that they have no competing interests.

\section{Authors' contributions}

ARR performed all experiments and statistical analysis and drafted the manuscript. GAU participated in the experimental design, supervised the research work, and was responsible for the final elaboration of the final manuscript. GAU also provided technical and financial support for this study. Both authors read and approved the final manuscript.

\section{Acknowledgements}

This work was part of the Thematic Project no. 2008/10449-7 financed by FAPESP - Fundação de Amparo a Pesquisa do Estado de São Paulo. ARR thanks FAPESP also for the master fellowship, process no. 2009/12737-2. ARR and GAU thank Alain Devaux, Sylvie Bony, Maria Beatriz Bohrer-Morel, Errol Zeiger, and Harold Freeman for the valuable suggestions, Francine Inforçato Vacchi for helping with the manuscript organization, and Erika Rabello Moretti for helping with the reproductive assay. 
Received: 26 May 2014 Accepted: 1 August 2014

Published: 21 August 2014

\section{References}

1. ETAD: The Ecological and Toxicological Association of Dyes and Organic Pigments Manufacturers, Annual Review. 2012. Issued April 2013 [www.etad. com/documents/Downloads/publications/etad_+ar+2012_final_web.pdf]

2. Novotný C, Dias N, Kapanen A, Malachová K, Vándrovcová M, Itävaara M, Lima N: Comparative use of bacterial, algal and protozoan test to study toxicity of azo- and anthraquinone dyes. Chemosphere 2006, 63:1436-1442

3. Chung KT, Cerniglia CE: Mutagenicity of azo dyes: structure-activity relationships. Mutat Res-Rev Genet 1992, 277(Suppl 3):201-220.

4. Hanger K: Industrial dyes: Chemistry, Properties and Applications, Health and Safety Aspects. Germany: Wiley-VCH; 2003.

5. USEPA: Aerobic and Aerobic Treatment of C.I. Disperse Blue 79. US Department of Commerce. National Technical Information Service (NTIS) vols I and II. EPA/600/2-89/051 (PB 90-111642); 1989. http://nepis.epa.gov/ Exe/ZyPURL.cgi?.Dockey=2000TM97.txt.

6. Umbuzeiro GA, Roubicek DA, Rech CM, Sato MIZ, Claxton LD: Investigating the sources of the mutagenic activity found in a river using the Salmonella assay and different water extraction procedures. Chemosphere 2004, 54(Suppl 11):1589-1597.

7. Umbuzeiro GA, Freeman HS, Warren SH, Oliveira DP, Terao Y, Watanabe T, Claxton LD: The contribution of azo dyes to the mutagenic activity of Cristais River. Chemosphere 2005, 60(Suppl1):55-64.

8. Maguire RJ: Occurrence and persistence of dyes in a Canadian River. Water Sci Technol 1992, 25:264-270.

9. Oliveira DP, Carneiro PA, Rech CM, Zanoni MV, Clauton LD, Umbuzeiro GA: Mutagenic compounds generated from the chlorination of disperse azo dyes and their presence in drinking water. Environ Sci Technol 2006, 40(Suppl 21):6682-6689.

10. Ferraz ERA, Umbuzeiro GA, De Almeida G, Caloto Oliveira A, Chequer FMD, Zanoni MVB, Dorta DJ, Oliveira DP: Differential toxicity of disperse red 1 and disperse red 13 in the Ames test, HepG2 cytotoxicity assay, and Daphnia acute toxicity test. Environ Toxicol 2011, 26:489-497.

11. Vacchi Fl, Albuquerque AF, Vendemiatti JAS, Morales DA, Ormond AB, Freeman HS, Zocolo GJ, Zanoni MVB, Umbuzeiro GA: Chlorine disinfection of dye wastewater: Implications for a commercial azo dye mixture. Sci Total Environ 2013, 442:302-309.

12. OECD (Organization for Economic Co-operation and Development): Harmonized Integrated Hazard Classification System for Chemical Substances and Mixtures. Paris: OECD; 2001

13. Carneiro PA, Umbuzeiro GA, Oliveira DP, Zanoni MVB: Assessment of water contamination caused by a mutagenic textile effluent/dyehouse effluent bearing disperse dyes. J Hazard Mater 2010, 174:694-699.

14. Calevro F, Filipi Deri P, Albertosi C, Batistoni R: Toxic effects of aluminum, chromium and cadmium in intact and regenerating freshwater planarians. Chemosphere 1998, 37:651-659.

15. Preza DLC, Smith D: Use of newborn Girardia tigrina (Girard, 1850) in acute toxicity tests. Ecotoxicol Environ Safety 2001, 50:1-3.

16. Horvat T, Kalafatic M, Kopjar N, Kavačevic G: Toxicity testing of herbicide norflurazon on an aquatic bioindicator species - the planarians Polycelis feline (Daly). Aquat Toxicol 2005, 73:342-352.

17. Barros GS, Angelis DF, Furlan LT, Corrêa-Junior B: Use of freshwater planarians Dugesia (Girardia) tigrina testing toxicity of a petroleum refinery wastewater. J Braz Soc Ecotoxicol 2006, 1:67-70 (in Portuguese).

18. Kalafatic M, Kopjar N, Besendorfer $\mathrm{V}$ : The impairments of neoblast division in regenerating planarian Polycelis felina (Daly.) caused by in vitro treatment with cadmium sulfate. Toxicol in Vitro 2004, 19:99-107.

19. Kalafatic M, Kovačevic $G$, Franjevic D: Resistance of two planarians species to UV-irradiation. Folia Biol-Prague 2006, 54:103-108.

20. Knakievicz T, Ferreira HB: Evaluation of copper effects upon Girardia tigrina freshwater planarians based on a set of biomarkers. Chemosphere 2008, 71:419-428.

21. Mei-Hui L: Effects of nonionic and ionic surfactants on survival, oxidative stress, and cholinesterase activity of planarian. Chemosphere 2008, 70:1796-1803.

22. Knakievicz T, Vieira SM, Erdtmann B, Ferreira HB: Reproductive modes and life cycles of freshwater planarians (Platyhelminthes, Tricladida, Paludicula) from southern Brazil. Invertebr Biol 2006, 125:212-221.
23. Fukushima M, Funabiki I, Hashizume T, Osada K, Yoshida W, Ishida S: Detection and changes in levels of testosterone during spermatogenesis in the freshwater planarian Bdellocephala brunnea. Zool Sci 2008, 25:760-765.

24. Newmark PA, Sánchez-Alvarado A: Not your father's planarian: a classic model enters the era of functional genomics. Nat Rev Genet 2002, 3:210-219.

25. Buttarelli FR, Pellicano C, Pontieri FE: Neuropharmacology and behavior in planarians: translations to mammals. Comp Biochem Physiol C Toxicol Pharmacol 2008, 147(Suppl 4):399-408.

26. Franjevic $D$, Krajna A, Kalafatic M, Ljubešic $N$ : The effects of zinc upon the survival and regeneration of planarian Polycelis feline. Biologia 2000, 55:689-694.

27. Kato C, Mihashi K, Ishida S: Motility recovery during the process of regeneration in freshwater planarians. Behav Brain Res 2004, 150:9-14.

28. Iannaconne J, Tejada M: Employment of regeneration of freshwater planarian Girardia festae (Borelli, 1898) (Tricladida: Dugesiidae) to evaluate toxicity of Carbofuran. Neotrop Helminthol 2007, 1:7-14.

29. Medvedev IV: Regeneration in two freshwater planarian species exposed to methylmercury compounds. Russian I Devel Biol 2008, 39:232-235

30. Novikov W, Shieman IM, Fesenko EE: Effect of weak static and low-frequency alternation magnetic fields on the fission and regeneration of the planarian Dugesia (Girardia) tigrina. Bioelectromagnetics 2008, 29:387-393.

31. Reddien PW, Sánchez-Alvarado A: Fundamentals of planarian regeneration. Annu Rev Cell Dev Biol 2004, 20:725-757.

32. Saló E: The power of regeneration and the stem-cell kingdom: freshwater planarians (Platyhelminthes). Biogeosciences 2006, 28:546-559.

33. Guecheva T, Henriques JAP, Erdtmann B: Genotoxic effects of copper sulphate in freshwater planarian in vivo, studied with the single-cell gel test (comet assay). Mutat Res 2001, 497:19-27.

34. Gonzáles-Estévez C, Saló E: Autophagy and apoptosis in planarians. Apoptosis 2010, 15:279-292.

35. Aboobaker AA: Planarian stem cell: a simple paradigm for regeneration. Trends Cell Biol 2011, 21(Suppl 5):304-311.

36. Piontek M: Application of Dugesia tigrina Girard in toxicological studies of aquatic environments. Pol Arch Hydrobiol 1998, 45(Suppl 4):565-572.

37. Sáfadi RS: The use of freshwater planarians in acute toxicity tests with heavy metals. Verh Internat Limnol 1998, 26:2391-2392.

38. Orr PL, Hart DR, Craig GR: Guidance document on control of toxicity test precision using reference toxicants. Ottawa: Environmental Canada; 1990.

39. He L, Freeman HS, Lu L, Zhang S: Spectroscopic study of anthraquinone dye/amphiphile systems in binary aqueous/organic solvent mixtures. Dyes Pigments 2011, 91:389-395.

40. Kolasa J, Tyler S: Flatworms: Tuberllarians and Nemertea. In Ecology and classification of North American freshwater invertebrates. 2nd edition. Edited by Thorp JH, Covich AP. New York: AP; 2011.

41. Z̈nidaric D, Kalafatic M, Kopjar N: The survival of Hydra oligactis Pallas in unpleasant conditions. Zeitsch Angewan Zool 1995, 81:157-163.

42. Raffa RB, Desai P: Description and quantification of cocaine withdrawal signs in Planaria. Brain Res 2005, 1032:200-201.

43. Villar D, Schaeffer DJ: Morphogenetic action of neurotransmitters on regenerating planarians - a review. Biomed Environ Sci 1993 6(Suppl 4):327-347.

44. Baguñà J: The planarian neoblast: the rambling history of its origin and some current black boxes. Int J Dev Biol 2012, 56(Suppl1-3):19-37.

45. Cebrià F, Guo T, Jopek J, Newmark PA: Regeneration and maintenance of the planarian midline is regulated by a slit orthologue. Dev Biol 2007, 307:394-406.

46. Miyashita H, Nakagawa H, Kobayashi K, Hoshi M, Matsumoto M: Effects of $17 \beta$-estradiol and bisphenol $\mathrm{A}$ on the formation of reproductive organs in planarians. Biol Bull 2011, 220:47-56.

47. Vara DC, Leal-Zanchet AM, Lizardo-Daudt HM: Enbryonic development of Girardia tigrina (Girard, 1850) (Platyhelminthes, Tricladida, Paludicola). Bras J Biol 2008, 68(Suppl 4):889-895.

48. Benazzi M, Gremigni V: Developmental biology of triclad turberllarians (Planaria). In Developmental Biology of Freshwater Invertebrates. Edited by Harrison FW, Cowden RR. New York: Alan R Liss Inc; 1982:121-151. 
49. Dolci-Palma IA: Reproduction, eating and reaction to food in planarians under different maintenance conditions. Psicol USP 1995, 6(Suppl 1):173-196 (in Portuguese).

50. Lima OS: Total preparation of planarians and observations on digestion Sci Cult 1954, 6:162-164 (in Portuguese).

51. Hamilton MA, Russo RC, Thurston RV: Trimmed Spearman-Karber method for estimating median lethal concentrations in toxicity bioassays. Environ Sci Technol 1977, 11:714-719.

doi:10.1186/s12302-014-0022-5

Cite this article as: Ribeiro and Umbuzeiro: Effects of a textile azo dye on mortality, regeneration, and reproductive performance of the planarian, Girardia tigrina. Environmental Sciences Europe 2014 26:22.

\section{Submit your manuscript to a SpringerOpen ${ }^{\circ}$} journal and benefit from:

- Convenient online submission

- Rigorous peer review

- Immediate publication on acceptance

- Open access: articles freely available online

- High visibility within the field

- Retaining the copyright to your article 